Resultados: Se determinó la respuesta de anticuerpos en el fluido vaginal contra la hemolisisna producida por $G$. vaginalis, un agente común presente en la vaginosis bacteriana. La toxina purificada de $G$. vaginalis fue un antígeno útil para detectar la presencia de una respuesta inmune en los fluidos vaginales de las pacientes con vaginosis bacteriana independientemente de la cepa de G. vaginalis presente. Se detectó una respuesta específica de inmunoglobulina $\mathrm{A}$ en el $60 \%$ de las mujeres con vaginosis bacteriana evidente (puntaje de la tinción de Gram > 6) y en $18.5 \%$ de las mujeres con flora vaginal intermedia (puntaje de la tinción de Gram 4 a 6). La especificidad de la prueba fue de $91 \%$.

Conclusiones: Encontramos una correlación entre la respuesta inmune local específica contra la toxina de $G$. vagainalis y la vagnosis bacteriana. La forma altamente purificada de la toxina permite discriminar los desórdenes de la colonización oportunista por G. vaginalis.

\section{Seguimiento de una cohorte de 422 niños de 6 a 13 años de edad concebidos por fertilización in vitro}

François Olivennes, MD, Violaine Kerbrat, Midwife, Pierre Rufat, MD, Valérie Blanchet, Midwife, Renato Franchin, $\mathrm{MD}$, René Frydman MD*

\section{Department of Obstetrics and Gynecology, Antoine Béclère Hospital, Clamart, France}

\section{Fertil Steril 1997; 67: 284-289.}

Objetivo: Establecer contacto con la cohorte total de niños concebidos por FIV-TE en forma consecutiva en nuestro centro entre junio de 1981 y diciembre de 1988.

Diseño: Estudio retrospectivo.

Localización: Unidad de infertilidad del departamento de Obstetricia y ginecología, Hospital Antoine Béclère, Clamart, Francia.

Pacientes: Se obtuvo información completa de 370 niños. El porcentaje de pérdida de seguimiento fue del $9 \%$.

Intervenciones: Para determinar el bienestar de los niños, se usaron entrevistas telefónicas a los padres y se enviaron cuestionarios a los padres y/o pediatras.

Principales medidas de resultado: Procedimientos quirúrgicos, malformaciones, estatura y peso, desempeño escolar.

Resultados: El crecimiento físico de estos niños no mostró rasgos patológicos mayores, con solamente un $2.2 \%$ de ellos por debajo de las 2 desviaciones estándar para el peso y $0.3 \%$ para la estatura. Las tasas de malformaciones no fueron significativamente diferentes entre estos niños y la población general. El desempeño escolar fue bueno, un $92.2 \%$ presentó un resultado alentador. Cincuenta y ocho por ciento de los padres de niños entre los 6 y 10 años de edad no informaron a sus niños acerca de la FIV ni el $34 \%$ de los padres de los niños entre 11 y 13 años de edad. Posteriormente al nacimiento del niño de la FIV, 30 pacientes $(8.9 \%)$ tuvieron un embarazo espontáneo. Sin embargo, cinco de ellos $(15.1 \%)$ fueron ectópicos.
Conclusiones: Este estudio informa, por primera vez, datos que brindan confianza sobre el análisis a largo término de un gran grupo de niños mayores concebidos en forma consecutiva por FIV-TE, con un porcentaje bajo de sujetos perdidos del seguimiento.

\section{Tendencias cambiantes en el diagnóstico de endometriosis: un estudio comparativo de mujeres con endometriosis pélvica que se presentan con dolor pélvico crónico o infertilidad}

W. Paul Dmowski, MD., Ph.D*, Ryszard Lesniewicz, MD, Nasiruddin-Rana, MD., M.P.H., Peg Pepping, R.N., M.S., Motjaba Noursalehi, Ph.D.

\section{Institute for the Study and Treatment of Endometriosis, Chicago and Oak Brook, Illinois}

Fertil Steril 1997; 67: 238-243.

Objetivos: Comparar los datos demográficos, epidemiológicos y médicos y evaluar las tendencias diagnósticas en mujeres con endometriosis y síntomas de dolor pélvico crónico o endometriosis e infertilidad.

Diseño: Análisis retrospectivo.

Localización: Instituto para el Estudio y Tratamiento de la Endometriosis.

Pacientes: Seiscientas noventa y tres pacientes consecutivas con endometriosis y dolor pélvico crónico $(n=357)$ o endometriosis e infertilidad $(n=336)$.

Intervenciones: Ninguna.

Principales medidas de resultado: Parámetros demográficos y epidemiológicos, tendencias diagnósticas.

Resultados: Las mujeres con síntomas pélvicos fueron mas jóvenes, tenían menos educación formal, mayor frecuencia de historia familiar y mayor frecuencia e intensidad de quejas pélvicas. La edad promedio al primer síntoma $\mathrm{y}$ al diagnóstico fueron menores en el grupo de dolor, pero el estado de la endometriosis al momento del primer diagnóstico fue mas avanzado. El «retardo diagnóstico» promedio fue mas largo en el grupo de dolor pélvico que en el grupo de infertilidad (6.35 versus 3.13 años), pero disminuyó durante tres intervalos consecutivos de 5 años en ambos grupos, y también hubo un descenso gradual en la frecuencia de endometriosis avanzada en el momento del primer diagnóstico.

Conclusiones: Los parámetros demográficos y epidemiológicos en mujeres con endometriosis difieren, dependiendo de si los síntomas de presentación son dolor pélvico crónico o infertilidad. En el grupo de dolor, el retardo del diagnóstico es mayor y la endometriosis en el momento de la laparoscopia diagnóstica mas avanzada, indicando capacidad de progreso de la enfermedad. Durante los últimos 15 años, el retardo del diagnóstico tuvo una tendencia constante hacia la disminución y declinó la frecuencia de endometriosis avanzada al momento del primer diagnóstico. 